cholesterol. J Lipid Res 25:1450-146

22. Glomset JA 1968 The plasma lecithin cholesterol acyltransferase reaction. J Lipid Res 9:155-167

23. Koren E, McConathy WJ, Alaupovic P 1982 Isolation and characterization of simple and complex lipoproteins containing apolipoprotein $F$ from human plasma. Biochemistry 21:5347-5351

24. Sweeney MJ. Etteldorf JN, Troop LJ. Timma DL, Wrenn EL 1963 Diet and fatty acid distribution in subcutaneous fat and in the cholesterol-triglyceride fraction of serum of young infants. J Clin Invest 42:1-9

25. Dayton S, Hashimoto S, Pearce ML 1966 Composition of lipids in human serum and adipose tissue during prolonged feeding of a diet high in unsaturated fat. J Lipid Res 7:103-111

26. Singer SJ 1974 The molecular organization of membranes. Ann Rev Biochem 43:805-833

27. Cannon PJ 1984 Eicosanoids and the blood vessel wall. Circulation 70:523528

\title{
Announcements
}

\section{New Horizons in Children's Heart Disease}

On May 28-30 “New Horizons in Children's Heart Disease, An International Symposium” will be held in Toronto, Canada. It is sponsored by the The Hospital for Sick Children and the University of Toronto.

Inquiries: Ms. Ellen Hornung, Department of Cardiology, The Hospital for Sick Children, 555 University Avenue, Toronto, Canada M5G 1 X8, (416) 598-5918.

\section{Society for Behavioral Pediatrics}

The Society for Behavioral Pediatrics will hold its 4th Annual Scientific Meeting on May 9-10, 1986 in Washington, DC in conjunction with the APA-APS-SPR meetings at the Sheraton Washington Hotel. For further information and registration forms, please contact Ms. Noreen Spota at (215) 248-9168 or Dr. Candace Erickson at (212) 305-9862.

\section{Neonatal Screening in 1986 \\ Evian April 28-30, 1986}

European meeting organized by the French Association For The Screening of Metabolic Diseases. The chairman will be Professeur Jean Frézal. The topics include hyperphenylalaninaemias: definition and classification, diagnostic strategy, antenatal diagnosis, maternal PKU. Congenital hypothyroidism: etiological aspects, confirmatory procedures, follow-up results. Other screening programs. The language will be French-English.

For further information: Secretariat du Pr. J. Frézal, Clinique Robert Debré, Hôpital des Enfants Malades, 149, rue de Sèvres, 75743 PARIS Cedex 15, France.

\section{Lung Club}

The annual meeting of the Lung Club will be held at the SPR/APS meetings on Wednesday, May 7th, at 6:30 PM in the South Cotillion Room of the Washington-Sheraton Hotel. This year's speakers are Dr. Solbert Permutt on "Mechanical Interactions Between the Respiratory and Circulatory Systems" and Dr. Alan Jobe on "Ventilation, Lung Development and Lung Damage." Attendance at the Lung Club is open to all without fee. For further information contact Dr. Robert B. Mellins at 212-305-6551. 